\title{
Von Willebrand disease type 2
}

INSERM

\section{Source}

INSERM. (1999). Orphanet: an online rare disease and orphan drug data base. Von

Willebrand disease type 2. ORPHA:166081

Type 2 von Willebrand disease (type 2 VWD) is a form of VWD (see this term)

characterized by a bleeding disorder associated with a qualitative deficiency and functional anomalies of the Willebrand factor (von Willebrand factor; VWF). 